\title{
Anaerobic ensiling of raw agricultural waste with a fibrolytic enzyme cocktail as a cleaner and sustainable biological product
}

\author{
A.E. Kholif a , M.M.Y. Elghandour ${ }^{\text {b }}$, G.B. Rodríguez ${ }^{\text {c }}$, O.A. Olafadehan ${ }^{\text {d }}$, A.Z.M. Salem ${ }^{\text {b. * }}$ \\ a Dairy Science Department, National Research Centre, 33 Bohouth St., Dokki, Giza, Egypt \\ ${ }^{\mathrm{b}}$ Facultad de Medicina Veterinaria y Zootecnia, Universidad Autónoma del Estado de México, Mexico \\ ${ }^{\mathrm{c}}$ Centro Nacional de Investigación Disciplinaria en Fisiología y Mejoramiento Animal, INIFAP, Mexico \\ ${ }^{\mathrm{d}}$ Department of Animal Science, University of Abuja, Abuja, Nigeria
}

\section{A R T I C L E I N F O}

\section{Article history:}

Received 17 July 2016

Received in revised form

31 October 2016

Accepted 1 November 2016

Available online 3 November 2016

\section{Keywords:}

Anaerobic fermentation

Cleaner production

Ensiling

Exogenous enzyme

Fibrous feeds

\begin{abstract}
A B S T R A C T
The increasing expansion of agricultural activities have resulted in an unending production of agricultural waste which constitutes environmental nuisance, if not properly disposed. In most developing countries, this waste is burnt causing environmental problems and health challenges. The utilization of biodegraded ensiled agricultural waste, as an energy source, in livestock nutrition is proposed as a viable solution of reducing pollution. Agricultural waste such as straws is carbohydrate-rich materials that have a large potential as a dietary energy source for ruminants. This study aimed to determine the effect of anaerobic ensiling of raw agricultural waste with a fibrolytic enzyme cocktail as a cleaner and sustainable biological product for animal feed. Ten samples of $1 \mathrm{~kg}$ each of wheat straw, corn stalks and sugarcane bagasse were ensiled with enzyme cocktail at 0,1 or $3 \mathrm{~mL} / \mathrm{kg}$ dry matter of feed. Before ensiling, feed samples were chopped at $5 \mathrm{~cm}$ and moistened to a relative humidity of approximately $50 \%$ and then kept for $30 \mathrm{~d}$ in plastic bales. Feed type $\times$ enzyme level interactions were observed $(P<0.01)$ for nutrient contents and fermentation kinetics. Increasing the level of enzyme cocktail increased $(P<0.01)$ crude protein and ether extract contents but decreased organic matter and non-structural carbohydrates contents of the three feeds. The enzyme cocktail also decreased $(P<0.01)$ neutral detergent fiber, acid detergent fiber, cellulose and hemicellulose contents of corn stalks and sugarcane bagasse. The high level of the enzyme cocktail increased $(P<0.05)$ methane production from corn stalks but decreased it from sugarcane bagasse. Fermentation parameters response to ensiling differed among the ensiled feeds. It can be concluded that anaerobic fermentation of enzyme-treated agricultural waste and feeding it to livestock is one of the viable ways of utilizing this waste which otherwise could have constituted nuisance and pollution to the environment, if incinerated or improperly disposed.
\end{abstract}

๑) 2016 Elsevier Ltd. All rights reserved.

\section{Introduction}

Global crop production is growing continuously, with large amounts of crop residues being produced. Besides, the high cost of concentrates and quality forages has raised the interest to include fibrous roughages in ruminant nutrition, as indicated by Alsersy et al. (2015) in their work on effect of Mediterranean saltbush (Atriplex halimus) ensilaging with two enzyme cocktails on feed intake, nutrient digestibility and ruminal fermentation in sheep. Agricultural waste could either be anaerobically fermented and used as energy feeds for livestock, or disposed into the

\footnotetext{
* Corresponding author.

E-mail address: asalem70@yahoo.com (A.Z.M. Salem).
}

environment causing a serious pollution and nuisance, and its disposal becoming a costly issue to the resource-poor farmers. Faverial and Sierra (2014), studying home composting of household biodegradable waste under the tropical conditions of Guadeloupe, stated that there is a renewed attempt in expanding complementary technologies of managing organic waste that will divert them from landfill and abate the emissions of greenhouse gas. Anaerobic degradation of agricultural waste to produce ingredients that can be used for livestock feeding is a welcomed technology to reduce landfill by facilitating a sustainable supply of renewable energy. Agricultural waste, such as wheat straw, corn stalks and sugarcane bagasse, is a carbohydrate-rich organic waste or material with a large potential as a source of dietary energy for ruminants. This waste constitutes nuisance and pollution to the environment. 
However, when used as feeds, such feeds have poor feeding value due to low nutrient density and fibrous nature, as reported by Kholif et al. (2014) who evaluated nutrient digestibility, ruminal fermentation activities, serum parameters and milk production and composition of lactating goats fed diets containing rice straw treated with Pleurotus ostreatus. Feeding of ruminants depends mainly on fibrous forages as the main feeds, but the digestion of these forages in the rumen is limited by their high fiber and low protein contents. Khattab et al. (2013), in a study of chemical composition and in vitro digestibility of Pleurotus ostreatus treated spent rice straw, averred that the low digestion of the fibrous forage in the rumen cannot be ignored due to their consequences. Evaluating microbiology of the rumen in relation to the chemical or biological treatment of crops and by-products, Chesson (1984) stated that fibers at high level can prevent the access of ruminal hydrolytic enzymes and inhibit bacteria attachment to cellulose and hemicellulose. High fiber content with low digestibility of fibrous feeds limits their usage as sole feed for actively growing or high-performing ruminants.

Biodegradation of lignocellulose materials has been documented using exogenous enzymes, in a trial involving the effect of exogenous xylanase on rumen in vitro gas production (GP) and degradability of wheat straw, (Togtokhbayar et al., 2015). Exogenous enzymes direct inclusion or pretreatment of feeds is one of most effective methods employed to improve feed utilization in ruminant nutrition. Fibrolytic enzymes improve feed digestibility and increase fermentation in vitro (Elghandour et al., 2016), in vivo (Salem et al., 2015) and in sacco (Togtokhbayar et al., 2015). In their study of potential of feeding of goats on fibrous feeds supplemented with or without bacterial inoculums, Khattab et al. (2011) reported improved milk production and composition, and animal health. Morsy et al. (2016) fed two commercial enzyme products in a fibrous complete diet to lactating buffaloes and reported improved nutrient digestibility, milk production and composition, and milk efficiency. The present study aimed to explore the effect of anaerobic ensiling of wheat straw, corn stalks and sugarcane bagasse with a fibrolytic enzyme cocktail on nutrient profile, and in vitro gas and methane $\left(\mathrm{CH}_{4}\right)$ production as well as fermentation kinetics as a cleaner and sustainable biological product for animal feed.

\section{Materials and methods}

\subsection{Experimental design}

The effect of ensiling of three raw low nutritive fibrous feeds (wheat straw, corn stalks, and sugarcane bagasse) with a fibrolytic enzyme cocktail was evaluated. Samples of the fibrous feeds were collected from different sites and each feedstuff was bulked and mixed with the enzyme cocktail product.

The enzyme cocktail was studied for its enzyme activities according to the methods of Valdes et al. (2015). Analysis showed its enzyme activity as: $7.1 \mathrm{unit} / \mathrm{g}$ cellulases, $2.3 \mathrm{unit} / \mathrm{g}$ xylanases, 61.5 unit/g $\alpha$-amylase and 29.2 unit/g protease obtained through an anaerobic fermentation process.

Ten samples of $1 \mathrm{~kg}$ each of the fibrous feeds were chopped at $5 \mathrm{~cm}$ and mixed with the enzyme cocktail in plastic bales. Based on previous experiments recommendations (Khattab et al., 2011; Abdel-Aziz et al., 2015; Gado et al., 2016) with the same enzyme preparation, the enzyme cocktail was used at three levels of 0,1 or $3 \mathrm{~mL}$ enzyme/kg dry matter (DM) of feed. Feedstuffs were moistened to a relative humidity of approximately $50 \%$. Before ensiling, molasses was added to each feed at the rate of $10 \mathrm{~g} / \mathrm{kg}$ of DM and mixed thoroughly. The enzyme cocktail was then sprayed on the mixtures without changing the humidity content, and the mixtures were remixed. A baling machine was used to press the whole contents together then a plastic raving machine was used to isolate the whole contents from air and the contents were allowed to ferment anaerobically for $30 \mathrm{~d}$.

\subsection{In vitro fermentation}

Rumen inoculum was collected from two Brown Swiss cows (400-450 kg body weight) fitted with a permanent rumen cannula and fed ad libitum a formulated total mixed ration of a commercial concentrate (PURINA ${ }^{\circledR}$, Toluca, Mexico) and alfalfa hay in the ratio of 1:1 DM, according to NRC (2001). During collection phase, cows were offered fresh water ad libitum. Collected rumen contents were flushed with carbon dioxide, mixed and strained through four layers of cheesecloth into a flask with oxygen-free headspace. Samples $(0.5 \mathrm{~g})$ of each fibrous feed were weighed into $120 \mathrm{~mL}$ serum bottles and, subsequently, $10 \mathrm{~mL}$ of particle-free rumen fluid was added to each bottle followed by $40 \mathrm{~mL}$ of the buffer solution of Goering and Van Soest (1970), with no trypticase added. Three incubation runs were performed in three weeks. Bottles (three feeds $\times$ three levels of enzyme cocktail $\times$ four replicates $\times$ three different runs) plus three bottles as blanks (rumen fluid only) were incubated for $48 \mathrm{~h}$. Once all bottles were filled, they were immediately closed with rubber stoppers, shaken and placed in an incubator at $39^{\circ} \mathrm{C}$. The volume of GP was recorded at 2, 4, 6, 8, 10, $12,14,16,24$, and $48 \mathrm{~h}$ using the Pressure Transducer Technique (Extech instruments, Waltham, USA) of Theodorou et al. (1994). At the end of incubation at $48 \mathrm{~h}$, the fermentation process was stopped by swirling the bottles in ice. The bottles were then uncapped and the $\mathrm{pH}$ was measured using a $\mathrm{pH}$ meter (Conductronic pH15, Puebla, Mexico) and the contents of each bottle filtered under vacuum through glass crucibles (coarse porosity no. 1, pore size $100-160 \mu \mathrm{m}$; Pyrex, Stone, UK) with a sintered filter to obtain the non-fermented residue for determination of degraded substrate (i.e., DM degradability (DMD)) after drying at $65{ }^{\circ} \mathrm{C}$ overnight. After recording the final gas volume at $48 \mathrm{~h}$ of incubation, $2 \mathrm{~mL}$ of $\mathrm{NaOH}(10 \mathrm{M})$ were added to each bottle and gas pressure was determined immediately. Mixing of the contents with $\mathrm{NaOH}$ allowed absorption of carbon dioxide, with the gas volume remaining in the headspace of bottles considered to be $\mathrm{CH}_{4}$ (Demeyer et al., 1988).

\subsection{Chemical analysis}

Samples of ensiled fibrous feeds were dried and ground through a 1-mm screen (Wiley mill, Arthur H. Co., Philadelphia, PA, USA) and analyzed for DM (\#934.01), ash (\#942.05), nitrogen (\#954.01) and ether extract (EE; \#920.39) according to AOAC (1997). The neutral detergent fiber (NDF; Van Soest et al., 1991), acid detergent fiber (ADF) and lignin (AOAC, 1997; \#973.18) were analyzed using an ANKOM $^{200}$ Fiber Analyzer Unit (ANKOM Technology Corporation, Macedon, NY, USA). The NDF was assayed with heat-stable alpha-amylase and with sodium sulfite in the neutral detergent solution. Both NDF and ADF were expressed without residual ash. Non-structural carbohydrates (NSC), cellulose, hemicelluloses and organic matter $(\mathrm{OM})$ were calculated.

\subsection{Calculations and statistical analysis}

For estimation of GP kinetics, recorded gas volumes (mL/g DM) were fitted using the NLIN procedure of SAS (2004) according to France et al. (2000) model as:

$y=b \times\left[1-\mathrm{e}^{-c(t-L)}\right]$ 
where $y$ is the volume of GP at time $t(\mathrm{~h}) ; b$ is the asymptotic GP; $c$ is the fractional rate of fermentation $(/ \mathrm{h})$, and $L(\mathrm{~h})$ is the discrete lag time prior to when any gas is released. Values of $b, c$, and $L$ were used to calculate fitted gas volumes at different hours of incubation, and were not shown in the tables.

Metabolizable energy ( $\mathrm{ME}, \mathrm{MJ} / \mathrm{kg} \mathrm{DM}$ ) was estimated according to Menke et al. (1979) as: $\mathrm{ME}=2.20+0.136 \mathrm{GP}(\mathrm{mL} / 0.5 \mathrm{~g}$ $\mathrm{DM})+0.057$ crude protein $(\mathrm{CP} ; \mathrm{g} / \mathrm{kg} \mathrm{DM})$.

Where: GP is net GP in mL from $200 \mathrm{mg}$ of dry sample after $24 \mathrm{~h}$ of incubation.

The partitioning factor at $24 \mathrm{~h}$ of incubation $\left(\mathrm{PF}_{24}\right.$; a measure of fermentation efficiency) was calculated as the ratio of DMD in vitro $(\mathrm{mg} / \mathrm{g} \mathrm{DM})$ to the volume of gas $(\mathrm{mL})$ produced at $24 \mathrm{~h}$ (i.e., DMD/ total GP) according to Blümmel et al. (1997). Gas yields ( $\left.\mathrm{GY}_{24}\right)$ were calculated as the volume of gas produced after $24 \mathrm{~h}$ ( $\mathrm{mL}$ gas/g DM) of incubation divided by the amount of DMD (g) as: $\mathrm{GY}_{24} \mathrm{~mL}$ gas per g DM per g DMD.

Short chain fatty acid concentrations (SCFA) and microbial CP (MCP) productions were calculated according to Getachew et al. (2002).

\subsection{Statistical analyses}

Data of each of the three runs for the samples of each of the three fibrous feed were averaged prior to statistical analysis, and mean values of each individual sample were used as the experimental unit. Results were analyzed as a factorial experiment using the PROC GLM option of SAS (2004) as:

$\mathrm{Y}_{\mathrm{ijk}}=\mu+\mathrm{F}_{\mathrm{i}}+\mathrm{L}_{\mathrm{j}}+\left(\mathrm{F} \times \mathrm{L}_{\mathrm{ij}}+\mathrm{E}_{\mathrm{ijk}}\right.$

Where: $\mathrm{Y}_{\mathrm{ijk}}=$ is every observation of the $i$ th feed $\left(\mathrm{F}_{\mathrm{i}}\right)$ with $j$ th enzyme level $\left(\mathrm{L}_{\mathrm{j}}\right) ; \mu$ is the general mean; $(\mathrm{F} \times \mathrm{L})_{\mathrm{ij}}$ is the interaction between feed type and enzyme level; $E_{i j k}$ is the experimental error. Statistical significance was declared at $P<0.05$.

\section{Results}

\subsection{Feeds nutrient content}

Nutrient contents were different $(P<0.05)$ among the three fibrous feeds. For all determined nutrient contents, feed type $\times$ enzyme level interactions were observed $(P<0.001)$. For all crop residues, increasing the level of the enzyme cocktail increased $\mathrm{CP}$ and EE $(P<0.001)$ contents, decreased OM $(P<0.05)$ and NSC $(P<0.001)$ contents, and had no effect on other nutrients for wheat straw and DM content for corn stalks. Ensiling of corn stalks with the enzyme cocktail at 1 and $3 \mathrm{~mL} / \mathrm{kg}$ DM decreased its contents of NDF $(P=0.001)$, ADF $(P=0.003)$, cellulose $(P=0.010)$, and hemicellulose $(P<0.001)$. All determined nutrients of sugarcane bagasse were affected by the enzyme cocktail level, while decreased $(P<0.001)$ contents of NDF, ADF, cellulose, and hemicellulose were observed with 1 and $3 \mathrm{~mL} / \mathrm{kg}$ DM enzyme levels (Table 1).

\subsection{In vitro gas and methane productions, and fermentation kinetics}

Feed type $\times$ enzyme level interactions were observed $(P<0.05)$ for gas and $\mathrm{CH}_{4}$ productions at $48 \mathrm{~h}$ incubation, $\mathrm{pH}, \mathrm{DMD}, \mathrm{ME}, \mathrm{SCFA}$, $\mathrm{PF}_{24}, \mathrm{MCP}$, and $\mathrm{GY}_{24}$ (Table 2). Fig. 1 shows the in vitro rumen GP $(\mathrm{mL} / \mathrm{g}$ incubated $\mathrm{DM})$ of wheat straw, corn stalks and sugarcane bagasse as affected by different levels of a fibrolytic enzyme cocktail during $48 \mathrm{~h}$ of incubation. For wheat straw, the $3 \mathrm{~mL} / \mathrm{kg} \mathrm{DM}$ enzyme level increased GP $(P=0.001), \mathrm{CH}_{4}$ production $(P=0.034)$, ME $(P<0.001)$, SCFA $(P<0.001)$, MCP $(P<0.001)$, and $\mathrm{GY}_{24}$ $(P<0.001)$. Contrarily, the enzyme cocktail level did not affect $(P>0.05)$ gas and $\mathrm{CH}_{4}$ productions, DMD, SCFA, $\mathrm{PF}_{24}, \mathrm{MCP}$, and $\mathrm{GY}_{24}$ of corn stalks; but the $3 \mathrm{~mL} / \mathrm{kg}$ DM enzyme level had the highest $\mathrm{pH}$ $(P=0.004)$ while the $1 \mathrm{~mL} / \mathrm{kg}$ DM enzyme level had the highest ME $(P=0.019)$. Without affecting $(P>0.05) \mathrm{GP}$ at $48 \mathrm{~h}$ incubation, $\mathrm{pH}$, $\mathrm{ME}, \mathrm{SCF}, \mathrm{PF}_{24}, \mathrm{MCP}$, and $\mathrm{GY}_{24}$, the 1 and $3 \mathrm{~mL} / \mathrm{kg}$ DM enzyme cocktail levels decreased $\mathrm{CH}_{4}$ production of sugarcane bagasse, while the $3 \mathrm{~mL}$ enzyme cocktail/ $\mathrm{kg}$ DM reduced the DMD (Table 2).

\section{Discussion}

Vallejo et al. (2016), in the study of influence of cellulase or xylanase on the in vitro rumen GP and fermentation of corn stover, noted that the in vitro GP technique is a simple, powerful and sensitive screening tool to evaluate feed nutritive value and test efficacy of feed additives. In the present study, the significant interactions between enzyme level and fibrous feed type, for most of the measured parameters, reveal that the effectiveness of each enzyme level varied with the different fibrous feeds. Elghandour et al. (2016), in their study of influence of the addition of enzyme with or without pre-incubation on the in vitro ruminal fermentation of three fibrous feeds, noted that interaction between enzyme level and feed type indicates that enzyme-feed specificity is an important determinant of enzyme action. Some experiments observed significant interactions between enzyme level and forage type (Elghandour et al., 2016), while others (Arriola and Adesogan, 2013) observed lack of substrate $\times$ enzyme interactions, when effect of fibrolytic enzyme application on the digestibility of corn silage, alfalfa hay, two concentrates, and complete diets under simulated ruminal and pre-ruminal conditions was studied.

\subsection{Nutrient content}

In developing countries, burning of agricultural waste (crop residues) in open fields engenders environmental and healthrelated problems in the surrounding areas, as pointed out by Mor et al. (2016) who considered application of agro-waste rice husk ash for the removal of phosphate from the wastewater, but anaerobic fermentation and enzyme treatment of this waste can enhance its recycling as a valuable feed in livestock production. Ensiling with the enzyme cocktail improved the anaerobic bio-utilization of nutrient contents of the tested fibrous feeds by increasing protein and lowering fiber fraction concentrations. Fiber generally forms bulk, lock up dietary nutrients and hinders their digestibility and utilization. The implication of the reduced fiber content is that nutrients which could have been locked up and thus passed out in the feces and urine, with consequential increase in environmental pollution, would be available for utilization by the animals. For instance, high dietary fiber results in poor feed degradation, digestibility and utilization, and increased elimination and accumulation of nitrogen which poses environmental challenge. Until now, no specific modes of action of enzymes have been proved, and this is only subject to speculation. The anaerobic pretreatment of feed with fibrolytic enzyme cocktails may cause a preingestive enzymefeed interaction which may enable partial hydrolysis and bioutilization of NDF and ADF (Arriola and Adesogan, 2013). According to Krueger and Adesogan (2008), who examined the effects of different mixtures of enzymes on digestion and fermentation of bahiagrass hay, anaerobic hydrolysis of fibers by anaerobic microflora can release reducing sugars. Feng et al. (1996), working on effect of enzyme preparations on in situ and in vitro degradation and in vivo digestive characteristics of mature cool-season grass 
Table 1

Effect of anaerobic ensiling of composted wheat straw, corn stalks, and sugarcane bagasse with a fibrolytic enzyme cocktail for $30 \mathrm{~d}$ on nutrient content (g/kg DM).

\begin{tabular}{|c|c|c|c|c|c|c|c|c|c|c|}
\hline Feed & Enzyme level (mL/kg DM) & $\mathrm{DM}$ & $\mathrm{OM}$ & $\mathrm{CP}$ & $\mathrm{EE}$ & NSC & NDF & $\mathrm{ADF}$ & Cellulose & Hemicellulose \\
\hline \multirow[t]{5}{*}{ Wheat straw } & 0 & 872 & $811^{a}$ & $43^{c}$ & $14^{\mathrm{c}}$ & $122^{\mathrm{a}}$ & 633 & 421 & 522 & 212 \\
\hline & 1 & 880 & $793^{b}$ & $111^{\mathrm{b}}$ & $16^{\mathrm{b}}$ & $55^{\mathrm{b}}$ & 611 & 414 & 505 & 197 \\
\hline & 3 & 885 & $784^{\mathrm{b}}$ & $129^{\mathrm{a}}$ & $21^{\mathrm{a}}$ & $33^{c}$ & 601 & 411 & 499 & 190 \\
\hline & SEM & 95.1 & 8.1 & 6.6 & 0.3 & 12.2 & 43.9 & 41.7 & 29.2 & 20.4 \\
\hline & $P$ value & 0.817 & 0.022 & $<0.001$ & $<0.001$ & $<0.001$ & 0.424 & 0.257 & 0.391 & 0.236 \\
\hline \multirow[t]{5}{*}{ Corn stalks } & 0 & 901 & $822^{\mathrm{a}}$ & $41^{c}$ & $19^{\mathrm{b}}$ & $174^{\mathrm{a}}$ & $588^{\mathrm{a}}$ & $424^{\mathrm{a}}$ & $90^{\mathrm{a}}$ & $498^{\mathrm{a}}$ \\
\hline & 1 & 904 & $786^{\mathrm{b}}$ & $119^{b}$ & $22^{\mathrm{a}}$ & $102^{\mathrm{b}}$ & $543^{b}$ & $381^{\mathrm{b}}$ & $81^{\mathrm{b}}$ & $462^{\mathrm{b}}$ \\
\hline & 3 & 913 & $773^{\mathrm{b}}$ & $132^{\mathrm{a}}$ & $22^{\mathrm{a}}$ & $94^{c}$ & $525^{\mathrm{b}}$ & $373^{\mathrm{b}}$ & $78^{\mathrm{b}}$ & $447^{c}$ \\
\hline & SEM & 93.4 & 19.9 & 3.4 & 0.1 & 11.1 & 22.8 & 13.1 & 2.3 & 10.5 \\
\hline & $P$ value & 0.859 & $<0.001$ & $<0.001$ & $<0.001$ & $<0.001$ & 0.001 & 0.003 & 0.010 & $<0.001$ \\
\hline \multirow[t]{5}{*}{ Sugarcane bagasse } & 0 & 938 & $963^{a}$ & $29^{c}$ & $20^{c}$ & $181^{\mathrm{a}}$ & $733^{a}$ & $498^{\mathrm{a}}$ & $121^{\mathrm{a}}$ & $612^{\mathrm{a}}$ \\
\hline & 1 & 920 & $912^{\mathrm{b}}$ & $68^{\mathrm{b}}$ & $28^{\mathrm{b}}$ & $165^{\mathrm{b}}$ & $651^{\mathrm{b}}$ & $463^{b}$ & $111^{\mathrm{b}}$ & $540^{\mathrm{b}}$ \\
\hline & 3 & 926 & $887^{\mathrm{b}}$ & $89^{a}$ & $34^{\mathrm{a}}$ & $158^{\mathrm{b}}$ & $606^{c}$ & $444^{\mathrm{b}}$ & $96^{\mathrm{b}}$ & $510^{c}$ \\
\hline & SEM & 94.5 & 11.6 & 2.4 & 0.6 & 5.6 & 1.5 & 15.1 & 5.5 & 9.7 \\
\hline & $P$ value & 0.102 & 0.008 & $<0.001$ & $<0.001$ & $<0.001$ & $<0.001$ & $<0.001$ & $<0.001$ & $<0.001$ \\
\hline Pooled SEM & & 62.7 & 7.8 & 2.3 & 0.1 & 5.5 & 22.5 & 12.0 & 8.8 & 6.2 \\
\hline \multicolumn{11}{|l|}{$P$ value } \\
\hline Feed & & $<0.001$ & $<0.001$ & $<0.001$ & $<0.001$ & $<0.001$ & $<0.001$ & $<0.001$ & $<0.001$ & $<0.001$ \\
\hline Enzyme level & & 0.009 & $<0.001$ & $<0.001$ & $<0.001$ & $<0.001$ & $<0.001$ & $<0.001$ & $<0.001$ & $<0.001$ \\
\hline Feed type $\times$ Enzyme level & & $<0.001$ & $<0.001$ & $<0.001$ & $<0.001$ & $<0.001$ & $<0.001$ & $<0.001$ & $<0.001$ & $<0.001$ \\
\hline
\end{tabular}

For each feed, means within the same column with different letters differ $(P<0.05)$.

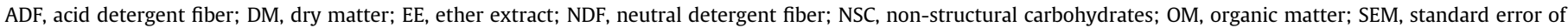
mean.

Table 2

Effect of ensiling wheat straw, corn stalks, and sugarcane bagasse with a fibrolytic enzyme cocktail for $30 \mathrm{~d}$ on fermentation kinetics after $48 \mathrm{~h}$ of incubation.

\begin{tabular}{|c|c|c|c|c|c|c|c|c|c|c|}
\hline \multirow[t]{2}{*}{ Feed } & \multirow[t]{2}{*}{ Enzyme level (mL/kg DM) } & \multicolumn{9}{|c|}{ Fermentation kinetics } \\
\hline & & Gas at $48 \mathrm{~h}$ & $\mathrm{CH}_{4}$ at $48 \mathrm{~h}$ & $\mathrm{pH}$ & DMD & ME & SCFA & $\mathrm{PF}_{24}$ & $\mathrm{MCP}$ & $\mathrm{GY}_{24}$ \\
\hline \multirow[t]{5}{*}{ Wheat straw } & 0 & $240^{\mathrm{b}}$ & $12.9^{\mathrm{ab}}$ & 6.68 & 531 & $5.98^{\mathrm{b}}$ & $2.86^{\mathrm{b}}$ & $6.20^{\mathrm{b}}$ & $519^{b}$ & $161^{\mathrm{c}}$ \\
\hline & 1 & $226^{\mathrm{b}}$ & $11.3^{\mathrm{b}}$ & 6.88 & 571 & $6.16^{\mathrm{b}}$ & $2.63^{\mathrm{b}}$ & $6.39^{\mathrm{a}}$ & $499^{\mathrm{b}}$ & $157^{\mathrm{b}}$ \\
\hline & 3 & $279^{\mathrm{a}}$ & $17.0^{\mathrm{a}}$ & 6.64 & 583 & $8.72^{\mathrm{a}}$ & $4.61^{\mathrm{a}}$ & $5.40^{\mathrm{c}}$ & $666^{\mathrm{a}}$ & $185^{\mathrm{a}}$ \\
\hline & SEM & 6.9 & 1.29 & 0.092 & 15.0 & 0.083 & 0.068 & 0.044 & 5.70 & 1.10 \\
\hline & $P$ value & 0.001 & 0.034 & 0.198 & 0.088 & $<0.001$ & $<0.001$ & $<0.001$ & $<0.001$ & $<0.001$ \\
\hline \multirow[t]{5}{*}{ Corn stalks } & 0 & 284 & 26.4 & $6.47^{\mathrm{b}}$ & 494 & $6.29^{\mathrm{b}}$ & 3.15 & 6.01 & 543 & 167 \\
\hline & 1 & 302 & 23.3 & $6.67^{\mathrm{ab}}$ & 478 & $7.00^{\mathrm{a}}$ & 3.37 & 5.89 & 562 & 170 \\
\hline & 3 & 279 & 22.7 & $6.81^{\mathrm{a}}$ & 464 & $6.71^{\mathrm{ab}}$ & 3.09 & 6.04 & 538 & 166 \\
\hline & SEM & 9.9 & 1.00 & 0.052 & 30.7 & 0.142 & 0.116 & 0.067 & 9.7 & 1.9 \\
\hline & $P$ value & 0.274 & 0.062 & 0.004 & 0.791 & 0.019 & 0.247 & 0.286 & 0.247 & 0.273 \\
\hline \multirow[t]{5}{*}{ Sugarcane bagasse } & 0 & 278 & $26.4^{\mathrm{a}}$ & 6.74 & $597^{\mathrm{a}}$ & 9.32 & 5.72 & 5.20 & 759 & 193 \\
\hline & 1 & 216 & $11.3^{\mathrm{b}}$ & 6.61 & $489^{\mathrm{ab}}$ & 8.38 & 4.69 & 5.37 & 672 & 186 \\
\hline & 3 & 301 & $8.0^{\mathrm{b}}$ & 6.67 & $357^{\mathrm{b}}$ & 9.91 & 5.61 & 5.17 & 751 & 194 \\
\hline & SEM & 25.8 & 2.1 & 0.05 & 33.8 & 0.511 & 0.418 & 0.100 & 35.2 & 3.5 \\
\hline & $P$ value & 0.107 & 0.001 & 0.207 & 0.002 & 0.156 & 0.213 & 0.335 & 0.213 & 0.301 \\
\hline $\begin{array}{l}\text { Pooled SEM } \\
P \text { value }\end{array}$ & & 16.4 & 1.52 & 0.068 & 27.7 & 0.310 & 0.253 & 0.074 & 21.3 & 2.40 \\
\hline Feed & & 0.021 & $<0.001$ & 0.308 & 0.001 & $<0.001$ & $<0.001$ & $<0.001$ & $<0.001$ & $<0.001$ \\
\hline Enzyme level & & 0.022 & $<0.001$ & 0.254 & 0.012 & $<0.001$ & 0.001 & $<0.001$ & $<0.001$ & $<0.001$ \\
\hline Feed $\times$ Enzyme level & & 0.028 & $<0.001$ & 0.005 & 0.004 & 0.003 & 0.004 & $<0.001$ & 0.004 & $<0.001$ \\
\hline
\end{tabular}

For each feed, means within the same column with different letters differ $(P<0.05)$.

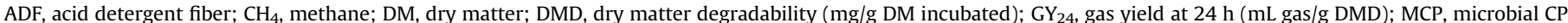

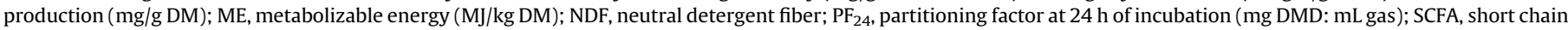
fatty acids (mmol/g DM); SEM, standard error of mean.

forage in beef steers, reported that enzyme treatment can modify plant cell wall structure resulting in increased fiber anaerobic digestion. Besides, treatment of feed with exogenous enzyme may enhance the binding of the enzyme to the feed and increase the resistance of the enzymes to ruminal proteolysis, as observed in the study on the resistance of cellulases and xylanases to proteolytic inactivation (Fontes et al., 1995). Improved initial rate of DM anaerobic digestion (Togtokhbayar et al., 2015), and increased bacterial colonization of feed particles are probable mechanisms as explained by Giraldo et al. (2008), in their study of effects of exogenous fibrolytic enzymes on in vitro ruminal fermentation of substrates with different forage: concentrate ratios.

The anaerobic pretreatment of the fibrous feeds with the enzyme cocktail before feeding encourages the biodegradation of fiber releasing the soluble carbohydrate components (Giraldo et al., 2008). This according to Wang et al. (2002), who investigated the effect of exogenous fibrolytic enzymes on epiphytic microbial populations and in vitro silage digestion, could stimulate production of anaerobic bacterial glycocalyx, and increase attraction of bacteria to the site of digestion. Releasing of soluble carbohydrates provides additional energy for ruminal microflora activity and shortens the lag time for microbial colonization in the rumen, as reported by Sutton et al. (2002) in their study of whole-crop wheat for dairy cows: effects of crop maturity, a silage inoculant and enzyme added before feeding on feed intake and digestibility and milk production. In line with the present results, using the same 

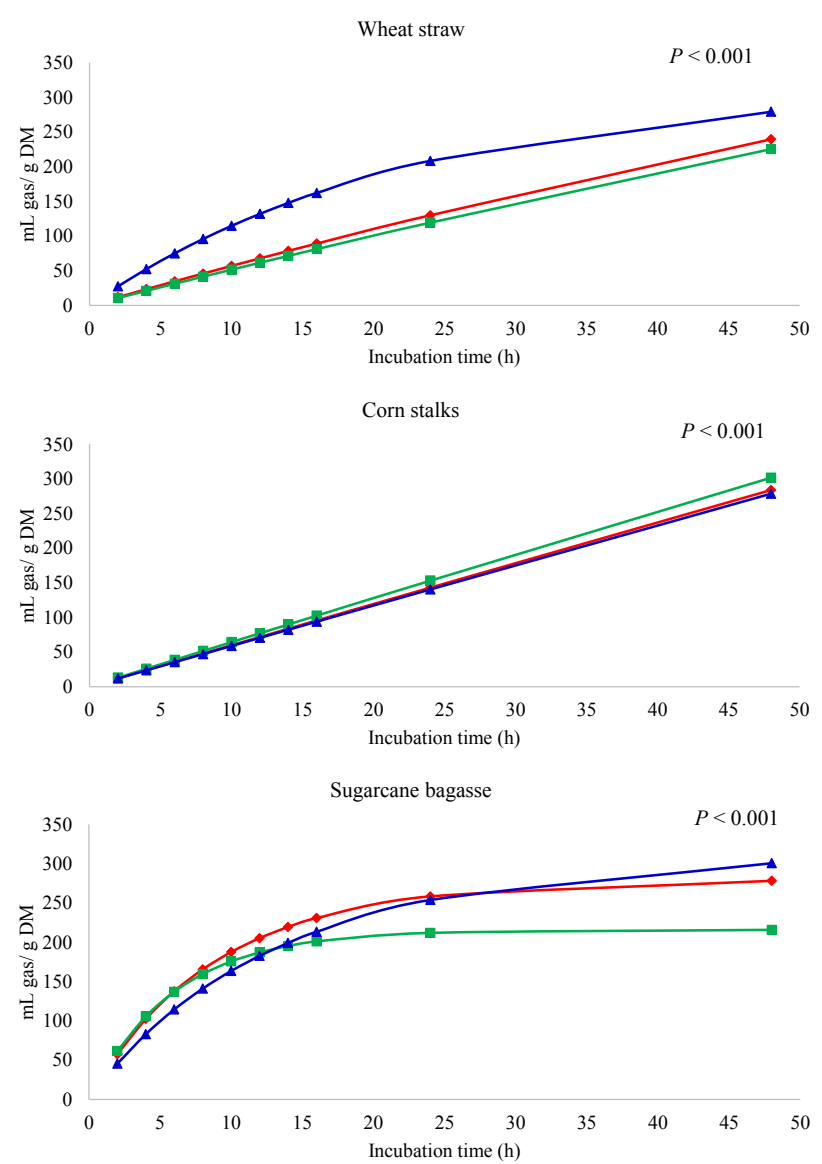

Fig. 1. In vitro rumen gas production ( $\mathrm{mL} / \mathrm{g}$ incubated $\mathrm{DM})$ of wheat straw, corn stalks and sugarcane bagasse as affected by different levels of a fibrolytic enzyme cocktail during $48 \mathrm{~h}$ of incubation at $0(--), 1$ (- - ), and $3\left(-\mathbf{\Lambda}_{-}\right) \mathrm{mL} / \mathrm{kg} \mathrm{DM}$.

enzyme cocktail, Khattab et al. (2011) reported that treating poorquality feed anaerobically with exogenous fibrolytic enzymes is accompanied by biodegradation of various fiber fractions. According to Facchini et al. (2011), who studied the optimization of fibrolytic enzyme production by Aspergillus japonicus with potential application in ruminant feed, the biodegradation of the various fiber fractions is as a result of decrease in the amount of the structural carbohydrate components. Alsersy et al. (2015), working on the same enzyme used in the current trial in their study of effect of Mediterranean saltbush (Atriplex halimus) ensilaging with two enzyme cocktails on feed intake, nutrient digestibility and ruminal fermentation in sheep, observed biodegradation of structural carbohydrate components of the diets by the enzyme cocktails.

\subsection{Gas and methane productions}

Gas production response to enzyme treatment differed among the fibrous feeds, in agreement with Gado et al. (2017) who attributed GP response to enzyme level $\times$ feed type interactions to different nutrient contents of each feed in their study of rumen degradation and nutritive utilization of wheat straw, corn stalks and sugarcane bagasse ensiled with multienzymes. Differences in fiber, and fiber fraction contents, proportions, composition and structure are the main reasons (Elghandour et al., 2016). Testing different levels of enzyme with different fibrous feeds is very important to identify the optimum enzyme level for a particular forage. Elghandour et al. (2015) evaluated influence of individual or mixed cellulase and xylanase mixture on in vitro rumen GP kinetics of total mixed rations and observed that effects of a fibrolytic enzyme on ruminal fermentation are substrate dependent. In the present study, enzyme treatment of wheat straw produced more gas at the level of $3 \mathrm{~mL} / \mathrm{kg}$ DM than the level of $1 \mathrm{~mL} / \mathrm{kg}$ DM. This is expected because the greater the enzyme level, the higher the enzymatic activity (Elghandour et al., 2016). However, increasing enzyme level can negatively affect feed utilization because higher enzyme level may prevent binding of enzymes to substrate receptors, and reduce proportional attachment of ruminal microorganisms to fiber (Togtokhbayar et al., 2015).

Increased GP with the high level of enzyme suggests a stimulated ruminal fermentation because GP is closely correlated with the amount of OM fermented, as reported by Díaz et al. (2013) when they examined in vitro evaluation of commercial fibrolytic enzymes for improving the nutritive value of low-quality forages. The pretreatment of wheat straw with the enzyme cocktail facilitated the access of ruminal microorganisms, due to degradation of some cell wall constituents. The obtained results suggest that the enzyme treatment at $3 \mathrm{~mL} / \mathrm{kg}$ DM can be used as a means to overcome the problem of low intakes and slow digestion of wheat straw.

Regarding the effect of the enzyme cocktail pretreatment on $\mathrm{CH}_{4}$ production, the response differed among tested feeds. The level $3 \mathrm{~mL}$ enzyme/kg DM increased $\mathrm{CH}_{4}$ production from wheat straw; however, the same level decreased $\mathrm{CH}_{4}$ production from sugarcane bagasse but did not affect the $\mathrm{CH}_{4}$ production from corn stalks. Again, the significant interaction between feed type and enzyme level reveals the importance of testing different levels of enzyme with different fibrous feeds to identify the optimum enzyme level for a particular forage. In few studies where the effects of fibrolytic enzymes on ruminal $\mathrm{CH}_{4}$ production were investigated, the results were inconsistent, as indicated by Kholif et al. (2016) in their reports on in vitro assessment of fecal inocula from horses fed on high-fiber diets with fibrolytic enzymes addition on gas, $\mathrm{CH}_{4}$, and carbon dioxide productions as indicators of hindgut activity. According to Tang et al. (2013), who worked on effects of exogenous cellulase source on in vitro fermentation characteristics and $\mathrm{CH}_{4}$ production of crop straws and grasses, when a ruminant animal is fed a diet with a good-quality forage, it produces less $\mathrm{CH}_{4}$ compared with highly fibrous diets. In the rumen, the methanogenic Archaea can utilize hydrogen produced during OM degradation for $\mathrm{CH}_{4}$ production. Decreased $\mathrm{CH}_{4}$ production of sugarcane bagasse may be related to its soluble carbohydrate contents, especially sucrose which has been reported to provide energy that leads to rapid microbial growth of ruminal non-methanogenic microorganisms (Elghandour et al., 2016). Mao et al. (2013), in the study of synergistic effect of cellulase and xylanase on in vitro rumen fermentation and microbial population with rice straw as substrate, reported increased $\mathrm{CH}_{4}$ production with the addition of cellulase and xylanases, but Shojaeian and Thakur (2007), evaluating the effect of exogenous fibrolytic enzymes supplementation to substrates containing different roughage:concentrate ratios on in vitro rumen fermentation, DM and NDF degradability, reported a decreased $\mathrm{CH}_{4}$ production with fiber degrading enzymes.

\subsection{Fermentation kinetics}

Enzyme cocktail at $3 \mathrm{~mL} / \mathrm{kg}$ DM increased ME, SCFA, MCP, and $\mathrm{GY}_{24}$ from wheat straw but its effect on fermentation kinetics of corn stalks and sugarcane bagasse was weak. The variation in results, at the same enzyme level, may be related to the differences in the nutrient content and structure of each feed. Improved production of SCFA and ME is positively correlated with high activities of the rumen microbes. Enzyme pretreatment can stimulate rumen microbial growth and activity causing improved SCFA production 
and ME concentration, as observed by Vallejo et al. (2016) who reported that the stimulation of microbial growth and activity in the rumen inoculum enhanced the production of SCFA and ME. Moreover, the improved fermentation of feeds with the enzyme pretreatment is related to enhanced fiber degradation and alterations in ruminal fermentation. Nsereko et al. (2002) studied effect of a fibrolytic enzyme preparation from Trichoderma longibrachiatum on the rumen microbial population of dairy cows and reported improved fiber digestion and altered ruminal fermentation due to enzyme treatment. Also, improved attachment and colonization of plant cell materials by rumen microorganisms (Nsereko et al., 2002) is another reason. Our results agree with those of Elghandour et al. (2016) who observed that addition of exogenous fibrolytic enzymes to feeds improved fermentation kinetics, ME, SCFA, MCP and DMD.

\section{Conclusions}

Anaerobic ensiling of enzyme-treated agricultural waste such as straws and their utilization as a source of dietary energy for ruminants can help mitigate environmental pollution due to burning of this waste in most developing countries. The study establishes anaerobic ensiling of raw agricultural waste with a fibrolytic enzyme cocktail as a means of producing cleaner and sustainable biological product for animal feed and solving the environmental problem caused by its disposal. The use of enzyme cocktail enhanced the anaerobic bio-utilization of nutrient contents and the biodegradation of fibrous feeds used, in the current study. Treatment of fibrous feeds with $3 \mathrm{~mL} / \mathrm{kg}$ DM enzyme level improved the DM, NDF and ADF biodegradation more than $1 \mathrm{~mL} / \mathrm{kg}$ DM enzyme level. It is concluded that anaerobic fermentation of enzymetreated agricultural waste and feeding it to livestock is one of the viable ways of utilizing this waste which otherwise could have constituted nuisance and pollution to the environment, if incinerated as practiced in the developing countries.

\section{Conflict of interest}

None.

\section{Acknowledgements}

Kholif, A.E. thanks the National Council for Science and Technology (CONACyT, Mexico) and The World Academy of Sciences (TWAS, Italy) for supporting his postdoctoral fellowship at the Facultad de Medicina Veterinaria y Zootecnia, Universidad Autónoma del Estado de México.

\section{References}

Abdel-Aziz, N.A., El-Adawy, M., Mariezcurrena-Berasain, M.A., Salem, A.Z., OlivaresPérez, J., Kholif, A.E., Borhami, B.E., 2015. Effects of exogenous enzymes, Lactobacillus acidophilus or their combination on feed performance response and carcass characteristics of rabbits fed sugarcane bagasse. J. Integ. Agric. 14 (3), 544-549.

Alsersy, H., Salem, A.Z.M., Borhami, B.E., Olivares, J., Gado, H.M. Mariezcurrena, M.D., Yacuot, M.H., Kholif, A.E., El-Adawy, M., Hernandez, S.R., 2015. Effect of Mediterranean saltbush (Atriplex halimus) ensilaging with two developed enzyme cocktails on feed intake, nutrient digestibility and ruminal fermentation in sheep. Anim. Sci. J. 86, 51-58.

AOAC, 1997. Official Methods of Analysis, sixteenth ed. Association of Official Analytical Chemists, Arlington, VA, USA.

Arriola, K.G., Adesogan, A.T., 2013. Effect of fibrolytic enzyme application on the digestibility of corn silage, alfalfa hay, two concentrates, and complete diets under simulated ruminal and preruminal conditions. Anim. Nutr. Feed Technol. 13, 537-550.

Blümmel, M., Steingass, H., Becker, K., 1997. The relationship between in vitro gas production, in vitro microbial biomass yield and $\mathrm{N}$ incorporation and its implications for the prediction of voluntary feed intake of roughages. Br. J. Nutr. 77
(6), 911-921.

Chesson, A., 1984. Microbiology of the rumen in relation to the chemical or biological treatment of crops and by-products. In: Proceedings of Second Seminar on the Upgrading of Crops and Byproducts: Improvements in the Nutritive Value of Crops and By-products by Chemical or Biological Treatments. Ministry of Agriculture, Fisheries and Food, London, UK, pp. 1-10.

Demeyer, D., De Meulemeester, M., De Graeve, K., Gupta, B.W., 1988. Effect of fungal treatment on nutritive value of straw. Int. S. Crop 53, 1811-1819.

Díaz, A., Carro, M.D., Saro, C., Mateos, I., Odongo, E., Ranilla, M.J., 2013. In vitro evaluation of commercial fibrolytic enzymes for improving the nutritive value of low-quality forages. Anim. Nutr. Feed Technol. 13, 461-476.

Elghandour, M.M.Y., Kholif, A.E., Marquez-Molina, O., Vazquez-Armijo, J.F, Puniya, A.K., Salem, A.Z.M., 2015. Influence of individual or mixed cellulase and xylanase mixture on in vitro rumen gas production kinetics of total mixed rations with different maize silage and concentrate ratios. Turk. J. Vet. Anim. Sci. 39 (4), 435-442.

Elghandour, M.M.Y., Kholif, A.E., Hernández, J., Mariezcurrena, M.D., López, S., Camacho, L.M., Márquez, O., Salem, A.Z.M., 2016. Influence of the addition of exogenous xylanase with or without pre-incubation on the in vitro ruminal fermentation of three fibrous feeds. Czech J. Anim. Sci. 61 (6), 262-272.

Facchini, F.D.A., Vici, A.C., Benassi, V.M., Freitas, L.A.P., Reis, R.A., Jorge, J.A., Terenzi, H.F., Polizeli, M.L.T.M., 2011. Optimization of fibrolytic enzyme production by Aspergillus japonicus $\mathrm{C} 03$ with potential application in ruminant feed and their effects on tropical forages hydrolysis. Bioproc. Biosyst. Eng. 34 1027-1038.

Faverial, J., Sierra, J., 2014. Home composting of household biodegradable wastes under the tropical conditions of Guadeloupe (French Antilles). J. Clean. Prod. 83, $238-244$.

Feng, P., Hunt, C.W., Pritchard, G.T., Julien, W.E., 1996. Effect of enzyme preparations on in situ and in vitro degradation and in vivo digestive characteristics of mature cool-season grass forage in beef steers. J. Anim. Sci. 74, 1349-1357.

Fontes, C.M.G.A., Hall, J., Hirst, B.H., Hazlewood, G.P., Gilbert, H.J., 1995. The resistance of cellulases and xylanases to proteolytic inactivation. Appl. Microbiol. Biotechnol. 43 (1), 52-57.

France, J., Dijkstra, J., Dhanoa, M.S., Lopez, S., Bannink, A., 2000. Estimating the extent of degradation of ruminant feeds from a description of their gas production profiles observed in vitro: derivation of models and other mathematical considerations. Br. J. Nutr. 83, 143-150.

Gado, H.M., Elghandour, M.M.Y., Cipriano, M., Odongo, N.E., Salem, A.Z.M., 2017 Rumen degradation and nutritive utilization of wheat straw, corn stalks and sugarcane bagasse ensiled with multienzymes. J. Appl. Anim. Res. 45, 485-489.

Gado, H.M., Kholif, A.E., Salem, A.Z., Elghandour, M.M., Olafadehan, O.A., Martinez, M.A., Al-Momani, A.Q., 2016. Fertility, mortality, milk output, and body thermoregulation of growing Hy-Plus rabbits fed on diets supplemented with multi-enzymes preparation. Trop. Anim. Health Prod. 48 (7), 1375-1380.

Getachew, G., Makkar, H.P.S., Becker, K., 2002. Tropical browses: contents of phenolic compounds, in vitro gas production and stoichiometric relationship between short chain fatty acid and in vitro gas production. J. Agric. Sci. 139, $341-352$.

Giraldo, L.A., Tejido, M.L., Ranilla, M.J., Carro, M.D., 2008. Effects of exogenous fibrolytic enzymes on in vitro ruminal fermentation of substrates with different forage:concentrate ratios. Anim. Feed Sci. Technol. 141, 306-325.

Goering, M.K., Van Soest, P.J., 1970. Forage Fiber Analysis (Apparatus, Reagents, Procedures and Some Applications). In: Agricultural Handbook, No. 379. Agricultural Research Services, USDA, Washington, DC, USA.

Khattab, H.M., Gado, H.M., Kholif, A.E., Mansour, A.M., Kholif, A.M., 2011. The potential of feeding goats sun dried rumen contents with or without bacteria inoculums as replacement for berseem clover and the effects on milk production and animal health. Int. J. Dairy Sci. 6, 267-277.

Khattab, H.M., Gado, H.M., Salem, A.Z.M., Camacho, L.M., El-Sayed, M.M., Kholif, A.M., ElShewy, A.A., Kholif, A.E., 2013. Chemical composition and in vitro digestibility of Pleurotus ostreatus spent rice straw. Anim. Nutr. Feed Technol. 13, 507-516.

Kholif, A.E., Khattab, H.M., El-Shewy, A.A., Salem, A.Z.M., Kholif, A.M., ElSayed, M.M., Gado, H.M., Mariezcurrena, M.D., 2014. Nutrient digestibility, ruminal fermentation activities, serum parameters and milk production and composition of lactating goats fed diets containing rice straw treated with Pleurotus ostreatus. Asian-Australas. J. Anim. Sci. 27, 357-364.

Kholif, A.E., Baza-García, L.A., Elghandour, M.M., Salem, A.Z., Barbabosa, A., Dominguez-Vara, I.A., Sanchez-Torres, J.E., 2016. In vitro assessment of fecal inocula from horses fed on high-fiber diets with fibrolytic enzymes addition on gas, methane, and carbon dioxide productions as indicators of hindgut activity. J. Equine Vet. Sci. 39, 44-50.

Krueger, N.A., Adesogan, A.T., 2008. Effects of different mixtures of fibrolytic enzymes on digestion and fermentation of bahiagrass hay. Anim. Feed Sci. Technol. 145, 84-94.

Mao, H.L., Wu, C.H., Wang, J.K., Liu, J.X., 2013. Synergistic effect of cellulase and xylanase on in vitro rumen fermentation and microbial population with rice straw as substrate. Anim. Nutr. Feed Technol. 13, 477-487.

Menke, K.H., Raab, L., Salewski, A., Steingass, H., Fritz, D., Schneider, W., 1979. The estimation of the digestibility and metabolizable energy content of ruminant feedingstuffs from the gas production when they are incubated with rumen liquor in vitro. J. Agric. Sci. 93, 217-222.

Mor, S., Chhoden, K., Ravindra, K., 2016. Application of agro-waste rice husk ash for the removal of phosphate from the wastewater. J. Clean. Prod. 129, 673-680. 
Morsy, T.A., Kholif, A.E., Kholif, S.M., Kholif, A.M., Sun, X., Salem, A.Z.M., 2016. Effects of two enzyme feed additives on digestion and milk production in lactating Egyptian buffaloes. Ann. Anim. Sci. 16 (1), 209-222.

NRC, 2001. Nutrient Requirements of Dairy Cattle, seventh revised ed. National Academy Press, Washington, DC, USA.

Nsereko, V.L., Beauchemin, K.A., Morgavi, D.P., Rode, L.M., Furtado, A.F. McAllister, T.A., Iwaasa, A.D., Yang, W.Z., Wang, Y., 2002. Effect of a fibrolytic enzyme preparation from Trichoderma longibrachiatum on the rumen microbial population of dairy cows. Can. J. Microbiol. 48, 14-20.

Salem, A.Z.M., Alsersy, H., Camacho, L.M., El-Adawy, M.M., Elghandour, M.M.Y. Kholif, A.E., Rivero, N., Alonso, M.U., Zaragoza, A., 2015. Feed intake, nutrient digestibility, nitrogen utilization, and ruminal fermentation activities in sheep fed Atriplex halimus ensiled with three developed enzyme cocktails. Czech J. Anim. Sci. 60 (4), 185-194.

SAS, 2004. Statistical Analysis System. User's Guide: Statistics. Version 9. SAS Institute Inc., Cary, NC, USA.

Shojaeian, K., Thakur, S.S., 2007. Effect of exogenous fibrolytic enzymes supplementation to substrates containing different roughage: concentrate ratios on in vitro rumen fermentation, DM and NDF degradability. Indian J. Dairy Sci. 60 (2), 94-101.

Sutton, J.D., Phipps, R.H., Deaville, E.R., Jones, A.K., Humphries, D.J., 2002. Wholecrop wheat for dairy cows: effects of crop maturity, a silage inoculant and enzyme added before feeding on food intake and digestibility and milk production. Anim. Sci. 74, 307-318.

Tang, S.X., Zou, Y., Wang, M., Salem, A.Z.M., Odongo, N.E., Zhou, C.S., Han, X.F., Tan, Z.L., Zhang, M., Fu, Y.F., Huang, S.Q., He, Z.X., Kang, J.H., 2013. Effects of exogenous cellulase source on in vitro fermentation characteristics and methane production of crop straws and grasses. Anim. Nutr. Feed Technol. 13, 489-505.

Theodorou, M.K., Williams, B.A., Dhanoa, M.S., McAllan, A.B., France, J., 1994. A simple gas production method using a pressure transducer to determine the fermentation kinetics of ruminant feeds. Anim. Feed Sci. Technol. 48, 185e197.

Togtokhbayar, N., Cerrillo, S.M.A., Jigjidpurev, S., Shinekhuu, J., Urantulkhuur, D., Nergui, D., Elghandour, M.M.Y., Odongo, N.E., Kholif, A.E., 2015. Effect of exogenous xylanase on rumen in vitro gas production and degradability of wheat straw. Anim. Sci. J. 86, 765-771.

Valdes, K.I., Salem, A.Z.M., Lopez, S., Alonso, M.U., Rivero, N., Elghandour, M.M.Y., Domínguez, I.A., Ronquillo, M.G., Kholif, A.E., 2015. Influence of exogenous enzymes in presence of Salix babylonica extract on digestibility, microbial protein synthesis and performance of lambs fed maize silage. J. Agric. Sci. 4, $732-742$.

Vallejo, L.H., Salem, A.Z.M., Kholif, A.E., Elghangour, M.M.Y., Fajardo, R.C., Rivero, N., Bastida, A.Z., Mariezcurrena, M.D., 2016. Influence of cellulase or xylanase on the in vitro rumen gas production and fermentation of corn stover. Indian J. Anim. Sci. 86 (1), 70-74.

Van Soest, P.J., Robertson, J.B., Lewis, B.A., 1991. Methods for dietary fiber, neutral detergent fiber, and nonstarch polysaccharides in relation to animal nutrition. J. Dairy Sci. 74, 3583-3597.

Wang, Y., McAllister, T.A., Rode, L.M., Beauchemin, K.A., Morgavi, D.P., Nsereko, V.L. Iwaasa, A.D., Yang, W., 2002. Effect of exogenous fibrolytic enzymes on epiphytic microbial populations and in vitro silage digestion. J. Sci. Food Agric. $82,760-768$. 